Aleksandr Kljucnikov,

Ph.D., University of Entrepreneurship and Law, The Czech Republic

ORCID ID: 0000-0003-0350-2658

email: kliuchnikov@gmail.com

Mehmet Civelek,

Ph.D., University of Entrepreneurship and Law, The Czech Republic

ORCID ID: 0000-0002-1247-5308

email:m_civelek@windowslive.com

Vladimir Krajcík,

Ph.D., University College of Business in Prague, The Czech Republic

ORCID ID: 0000-0003-2234-3939

email: vladimir.krajcik@vspp.cz

Jiri Polach,

Ph.D., University College of Business in Prague, The Czech Republic

ORCID ID: 0000-0002-2224-0414

email: polachj@vspp.cz

Correspondence author: kliuchnikov@gmail.com

\title{
CUSTOMER ATTITUDE TO THE LOCAL CURRENCY IMPLEMENTATION
}

Abstract. Carrying local currencies into practice in limited geographical regions has become a major obstacle to overcome due to awareness and trust of potential users. In this context, the purpose of this research is to explore and examine how trust and knowledge of potential users about local currencies differ between their genders and working experiences. In line with this target, the researchers gained data from 413 workers in Cieszyn Silesia region by using questionnaire surveys. Chi-Square and Z-score tests were calculated by SPSS statistical software to get statistically significant differences between the determining variables. The analyses corroborated nonexistence of statistically significant differences between genders and work experiences in the local currency knowledge of potential users. Most of the respondents in the analyzed region were aware of local currencies. Publicity and prevalence of local currencies and mutual interactions between employees might be the reasons for the similarities in the knowledge of potential users. Furthermore, this study confirms that trust of workers differs regarding their gender and work experience. Comparing to men and more experienced potential users, the propensity of women and less experienced employees to trust local currencies is higher. The reasons for these differences in gender and work experiences might stem from the education levels, perceptions, adoptions, instincts and interests of potential users regarding these currencies. These results can be mounting evidence to consider for institutions, organizations, governments and practitioners when implementing local currencies to increase the competitiveness of less developed regions. This study is only limited to a region, and the respondents are only employees. Other limitations are that this research examines two obstacles of the implementations of local currencies and two characteristics of respondents, namely, age and work experience.

Keywords: awareness, Cieszyn Silesia region, community currency, digital currency, gender, local currency, trust, work experience.

Introduction. Community currencies have become a catchy phenomenon during the last years due to their economic, social and environmental benefits, especially for local businesses and citizens. Developments in the online technologies and networks have also enabled those currencies to circulate via virtually in digital format. Cryptocurrencies are well-known examples of digital currencies, particularly

Cite as: Kljucnikov, A., Civelek, M., Krajcik, V., \& Polach, J. (2020). Customer attitude to the local currency implementation. Marketing and Management of Innovations, 4, 76-89. http://doi.org/10.21272/mmi.2020.4-06 
after the existence of Bitcoin. However, Bitcoin and other examples of cryptocurrencies such as Litecoin are not centralized digital currencies. Different from these currencies, this research will not only focus on paper-based local currencies but also will consider local digital currencies that process and are only limited in a geographical area as most of the community currencies circulate both virtually and paper-based.

This study presents one of the most frequently used classifications of CCs. In this classification, CCs are divided to four major types as service credits, mutual exchange systems, barter markets and local currencies (Michel and Hudon, 2015; Gimenez and Tamajon, 2019; Seyfang and Longhurst, 2013). But as stated before, local currencies (paper-based and digital) will be the main focus of this study.

The major goal of those currencies to play a complemental role for national currencies, enhance economic activities, encourage enterprises in locally (Michel and Hudon, 2015; Seyfang and Longhurst, 2013; Civelek et al., 2019), support local citizens to purchase or sell goods and services by creating networks with other people in a bounded region (Kim et al., 2016; Seyfang, 2005). Local currencies are completely different from national currencies because the currency that is processed by communities is not managed by the power of any national or federal authority (Blanc, 2011). The examples for famous community currencies are Regiogeld (Germany), Community Banks (Brazil), Ithaca Hours (USA) (Michel and Hudon, 2015; Seyfang and Longhurst, 2013) and Bristol Pounds (UK) (Ali et al., 2014).

When it comes to the Czech Republic, the first initiative regarding community currencies was attempted in 1999 (Frankova et al., 2014; Jelinek et al, 2012). Then some pilot studies and projects practised in some cities such as Hradec Kralove (Valek, 2012), Brno (RozLETSe, a pilot study by Frankova et al., 2014), CeskeBudejovice (acorn), Prague (chechtaky), Brno (letnicky) Jindrichovice pod Smrkem and Litomysl (Jelinek et al, 2012). Different from these practices, in this study, the authors analyzed research that based on potential users of a local currency in Cieszyn Silesia region of the Czech Republic. Purchasing power (Collom, 2007; Colacelli and Blackburn, 2009) and income (Wheatley et al., 2011; Collom, 2007; Ying, 2004) of people in communities increase by these currencies. This fact also increases local consumption (Bonanno, 2018; Josavac, 2017) and makes positive contributions on country's economic conditions (Colacelli and Blackburn, 2009). On the other hand, some factors of local currencies influence potential or existing users' tendencies and create difficulties in the implementation of these currencies and their wide usage. Perceived trustworthiness has seen as a big obstacle in the adoption of users by some studies (Shahzad et al., 2018; Carter et al., 2016) especially in case of lack of trust in financial institutions at all (Buriak et al., 2019). Lack of awareness of individuals is another constraint in the implementation of these currencies (Shahzad et al., 2018; Michel and Hudon, 2015). Therefore, this research will consider both of those barriers.

Moreover, the influences of local currencies on male and female users have also examined by some other studies (Seyfang, 2005; Walker, 2009). But these studies mostly focus on the advantages of these currencies for genders. Therefore, analyzing gender differences in the implementation barriers of local currencies might create value addition for the academic literature. On the other hand, studies in the literature mostly focus on previous users experience of community currencies (Gimenez and Tamajon, 2019; Gregory and Gregory, 2009) or administrative staff experience to manage those currencies (Sobiecki, 2018). When it comes to the users working experience and differences in their awareness and perceived trustfulness, there is not any study in the literature. In this regard, this study will be unique and will differ from other studies. The place of employment is the most significant place for learning of many workers by interacting with their colleagues (Paloniemi, 2006; Stacho et al., 2019). For instance, users can share their experiences in local currencies with their colleagues and friends and their perceived trustworthiness and this given information might affect their friends' willingness to use those currencies and might impact their motivations (Bonanno, 2018; Pena de Carrillo et al., 2018). In this regard, the workplace of potential users and their work experience in this workplaces might be an important factor to find differences among potential users' perceived trustworthiness and their awareness of those currencies. 
For the reasons mentioned above, this current research aims to explore differences between gender and working experience of potential users of local currencies regarding the most common constraints of usage and implementation of these currencies.

Thus, this study will try to find the answers to the following questions «Do potential users' awareness and trust regarding local currencies differ between more-less experienced and female-male potential users?». To find differences between selected characteristics, the researchers applied Chi-Square, Pearson and Z-score statistics. Finding differences between genders and work experience of potential might draw practitioners, academicians and policymakers attention when implementing community currency activities.

The other sections of this research will be provided as follows. Theoretical Background section will elucidate the background of this research. The purpose, the data, applied statistics and research methods of the study will be explained in section 3 . The results from the analyses, the potential practical and theoretical evidence of the findings and some policy implementations regarding the results will be outlined in section 4. In conclusion, the researchers will sum up the study briefly and present the highlights of the current research.

Literature Review. Community currencies provide advantages not only for individuals but also for enterprises and governments. For instance, while they increase job opportunities and improve the abilities of people, businesses gain benefits from them by increasing their sales potential, income and trading activities. Due to increasing income and revenues of individuals and firms, governments can get more tax yield. Business environment also carries high importance to implement community and local currencies. That is because many regulations are set by governments in the business environment to influence business operations, investment climate (Khan et al., 2019) and external financing of enterprises (Kljucnikov et al., 2019) and differences in economic conditions of firms are substantial factors in the business environment (Onuferova and Cabinova, 2018).

Moreover, since technology and digitalization transform conventional trading activities, they also influence the activities of local citizens and businesses by providing new chances to gain more income (Nwaiwu, 2018). In this regard, using local digital currencies also offer benefits to its users. These currencies also enhance social networks (Della Peruta and Torre, 2015; Bonanno, 2018; Sanz, 2016) and cooperative behaviours of its users (Colacelli and Blackburn, 2009). For these reasons, they also provide benefits for social development (Michel and Hudon, 2015). These social and economic improvements also make regions to be more competitive (Ginevicius, 2019).

Although local currencies provide benefits mentioned above for individuals and businesses, lack of awareness of society about meaning and usage of these currencies still creates one of the major obstacles for these currencies to put them into practices (Gregory \& Gregory, 2009; Brenes, 2011; Sobiecki, 2018). Some potential users even do not have any information whether these currencies are in existence in some communities. The reason for this obstacle stem from the publicity of those currencies (Williams et al., 2001).

Therefore, awareness about those currencies carries high importance in implementation and usage of local currencies. After being aware of its technologies, functioning and advantages, adaption and implementation of those currencies become easier (Sobiecki, 2018) because societies can change their decisions and they become more likely to use these currencies (Michel and Hudon, 2015; Sobiecki, 2018). Another main obstacle that influences the implementation of these currencies is a lack of trust of potential users (Williams et al., 2001; Marshall and O'Neill, 2018). When exchanging or making transactions with these currencies via paper-based and online or digital platforms, local people do not feel comfortable, and they might distrust these currencies. Therefore, it is one of the most significant factors that each CCs system needs to assure when making currencies applicable (Pena de Carrillo et al., 2018). Trust also has effects on adoption (Pena de Carrillo et al., 2018; Shahzad et al., 2018) and the satisfaction of users to 
local currencies (Pena de Carrillo et al., 2018). Shahzad et al. (2018) analyze the perceived trust of Bitcoin users and find a positive relationship between perceived trust and users' willing to apply Bitcoin.

The work experience might be a significant factor to consider, to find the differences in trust and awareness of potential users about local currencies. That is because by being more experienced, people can develop their personalities, learning, gaining experience and abilities by interacting with their colleagues (Paloniemi, 2006) and increasing the strength of their relations with other workers (Gimenez and Tamajon, 2019). So more experienced employees also become more experienced in teamwork, information interchange, creating more networks and getting more information from each other (Pena de Carrillo et al., 2018). Eventually, this experience has a positive impact on the overall social and economic development of the local community and state (Bilan et al., 2020). By investigating Spanish community currency users, Carnero et al. (2015) verify that most of the users are more than 35 years old. When employees get older, they become more experienced due to the positive relationship among both work experience and age ( $\mathrm{Ng}$ and Feldman, 2009). By experiencing more changes, new trends and other activities in working life and also having more knowledge in those processes, more experienced workers' perceived trustworthiness for a new trend such as local currencies might also be more positive. Zeffane (2018) also confirmed the positive influence of work experience on the propensity to trust.

Regarding gender differences in local currencies, Gomez and Helmsing (2008) state that local currencies have positive impacts on the autonomy of women, make them to gain abilities and to set up new enterprises. In this regard, local currencies motivate women to be more active socially and empower their roles in communities by providing special opportunities that only women can benefit (Gomez and Helmsing, 2008). Moreover, women can minimize gender inequality and have same conditions with men (Seyfang, 2005).

Therefore, local currencies are effective ways to cope with gender discrimination, that is one of the major problems of communities (Walker, 2009). Women users also perceive that the community currencies encourage them to gain more money (Seyfang, 2005), be more productive (Walker, 2009; Seyfang, 2005) so their income, economic power, financial and living conditions get better (Walker, 2009). By investigating the perception of potential women users Seyfang (2001), Williams et al. (2001) and Gomez and Helmsing (2008) find that women have more willingness to participate in community currency implementations. Similarly, Carnero et al. (2015), Collom (2007) and Lasker et al. (2011) indicate that most of the users of a community currency are women. For these reasons, women potential users also might have more knowledge about local currencies, and their reliability to these currencies might be more than their male counterparts. Moreover, some studies investigate the acceptance of the potential users in the usage of e-services and highlight that the perceived trust of males is lower than females (LiebanaCabanillas et al., 2018; Yeh et al., 2012).

Methodology and research methods. This paper aims to explore and analyze the perception of potential users about major implementation barriers of local and digital local currencies regarding their gender and work experience. In line with selected purpose, six survey questions were selected to measure the knowledge and trust of the respondents, to determine gender and work experience of the respondents. The substantiations of the mentioned researches in the literature review section (e.g. Zeffane, 2018; Liebana-Cabanillas et al., 2018; Yeh et al., 2012) make this study to hypothesize the following statements:

$\mathrm{H} 1$. There is a statistically significant difference between the local and digital currency awareness of potential users regarding their work experiences. The study assumes that more experienced respondents will be more informed about local currencies than their less experienced counterparts.

H2. A statistically significant difference exists between the trust of respondents to paper and local digital currencies regarding their work experience. The research supposes that more experienced potential users will be more likely to state that they trust or would trust local currencies in comparison with less experienced respondents. 
H3. There is a statistically significant difference between the local and digital currency knowledge of respondents regarding their gender. The study expects that potential female users will be more aware of the terms «local currency and digital currency» comparing to male respondents.

H4. A statistically significant difference exists between the reliability of respondents to paper and local digital currencies regarding their gender. The research presumes that women potential users will be more prone to trust or would rather trust local currencies than men respondents.

The survey question related to gender was directed to the respondents with two subcategories as man and woman. Moreover, to measure work experience of the potential users, the number of years that the respondents have been working for same company were asked with three choices. (less than 5 years, 5 to 10 years, and 10 years and more). However, work experience was recategorized to two categories for analyses purposes (less than 10 years and 10 and more years).

The following questions evaluated the obstacle regarding knowledge of potential users about local and digital currencies: Do you know the term local (community) currency? (Yes, No); Do you know the term digital currency? (Yes, No). When it comes to determining another implementation barrier that is the trust of potential users, the researchers have selected two following questions from the questionnaire: «Would you trust a DIGITAL local currency that is secured by a trusted entity (bank, state, significant large private enterprise) and whose exchange rate is firmly tied to the Czech koruna?» (Yes, Almost yes, Don't know, No) and «Would you trust a PAPER local currency that is secured by a trusted entity (bank, state, significant large private enterprise) and whose exchange rate is firmly tied to the Czech koruna?» (Yes, Almost yes, Don't know, No). The respondents are employees who work in one of the regions of the Czech Republic, namely, Cieszyn Silesia.

Chi-Square and Pearson's statistics were employed and evaluated at $5 \%$ confidence level to find the differences between male-female, and less-more experienced workers. $P$ values that are higher than this selected level of significance induce this research to reject the null hypotheses that suppose the fact that there are not any significant differences between the gender and experience of the potential user regarding their knowledge and trust of local and digital currencies.

Otherwise, the alternative hypotheses that assume the existence of differences among these examined variables of the respondents will be supported. Furthermore, the Z-score test was performed to find whether statistically significant differences exist in individual responses based on gender and experience. The research met with the requirements of the Z-score, such as the normal distribution of selected variables and $\mathrm{P}$ values from this distribution were considered by the researchers. For measuring the hypotheses, the calculations of this research were carried out by using SPSS Statistical Software Version 23.

For collecting the data that was examined by this research, a questionnaire survey was employed. This survey purposed to find out the perception of workers regarding the implementation of a local currency in Cieszyn Silesia. The research team selected a large regional producer with 5000 employees in all usual employee categories - workers, administrative staff, middle management, top management. After that, the researchers selected a sample of 500 employees, that clearly represented the whole data set according to gender, age, work experience, place of residence and marital status and distributed the questionnaires. 413 employees fulfilled the questionnaire survey that also included questions regarding the perception of these respondents about local currencies and its publicity. Moreover, the details about the characteristics of the survey respondents are presented below in Table 1.

Results. Table 2 depicts the results regarding differences in gender and experience of potential users about awareness of local currency. As specified, the following question was directed to respondents to evaluate their awareness «Do you know the term local (community) currency?». $52.8 \%$ of male, $54.5 \%$ female, $51.1 \%$ less experienced and $53.6 \%$ more experienced respondents are aware of this term, while other potential users do not know it. 
Table 1. The characteristics of potential users

\begin{tabular}{llcc}
\hline Variables & & \% of respondents & No. of respondents \\
\hline Gender & Men & $86.7 \%$ & 358 \\
& Women & $13.3 \%$ & 55 \\
\hline \multirow{2}{*}{ Age } & Less than 50 years & $59.3 \%$ & 245 \\
& 50 and more & $40.7 \%$ & 168 \\
\hline Work experience & Less than 10 years & $22.7 \%$ & 94 \\
& More than 10 years & $77.3 \%$ & 319 \\
\hline \multirow{4}{*}{ Marital Status } & Single & $16.7 \%$ & 69 \\
& Married & $66.8 \%$ & 276 \\
& Divorced & $16.5 \%$ & 68 \\
\hline \multirow{4}{*}{ Job position } & Administrative & $15 \%$ & 62 \\
& Manager & $6.3 \%$ & 26 \\
& Working product. & $66.4 \%$ & 274 \\
& Leader in manufac. & $8.7 \%$ & 36 \\
& Other positions & $3.6 \%$ & 15 \\
\hline \multirow{3}{*}{ Place of residence } & Trinec & $49.4 \%$ & 204 \\
& Jablunkov & $9.4 \%$ & 39 \\
& Bystrici & $7.0 \%$ & 29 \\
& Vendryne & $4.8 \%$ & 20 \\
& CeskýTešín & $4.4 \%$ & 18 \\
& Other regions & $24.9 \%$ & 103 \\
\hline
\end{tabular}

Sources: developed by the authors.

Table 2. The knowledge of potential users regarding local currency

\begin{tabular}{|c|c|c|c|c|}
\hline \multirow{2}{*}{$\begin{array}{l}\text { Do you know the term local (community) } \\
\text { currency? }\end{array}$} & \multicolumn{2}{|c|}{ Gender } & \multicolumn{2}{|c|}{ Experience (years) } \\
\hline & Male & Female & 10 and less & More than 10 \\
\hline 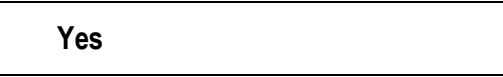 & $\begin{array}{c}189 \\
(52.8 \%)\end{array}$ & $\begin{array}{c}30 \\
(54.5 \%) \\
\end{array}$ & $\begin{array}{c}48 \\
(51.1 \%) \\
\end{array}$ & $\begin{array}{c}171 \\
(53.6 \%) \\
\end{array}$ \\
\hline No & $\begin{array}{c}169 \\
(47.2 \%)\end{array}$ & $\begin{array}{c}25 \\
(45.5 \%)\end{array}$ & $\begin{array}{c}46 \\
(48.9 \%)\end{array}$ & $\begin{array}{c}148 \\
(46.4 \%)\end{array}$ \\
\hline Total number of respondents & 358 & 55 & 94 & 319 \\
\hline $\begin{array}{l}\text { P-values from Chi-Square } \\
\text { P values from Z-score }\end{array}$ & 0,808 & & 0,664 & \\
\hline
\end{tabular}

Sources: developed by the authors.

When it comes to $P$ values from Chi-Square test and $Z$-score regarding gender $(x 2=0,808, z=0,8103)$, it can be clarified that a statistically significant difference between male and female respondents does not exist regarding their awareness of local currency. Similarly, $P$ values from both tests Chi-Square and Zscore for experience $(x 2=0,664, z=0,6672)$ also confirm the nonexistence of a statistically significant difference between more experienced and less experienced potential users. That is because both $p$ values from Chi-Square and Z-score tests are higher than $5 \%$ confidence level. To conclude, it can be inferred that knowledge of potential users about local currencies do not differ regarding their gender and work experience.

Table 3 illustrated the findings of this research regarding the respondents' knowledge of the term digital currency by focusing on their gender and work experience. For measuring potential users' knowledge, the following question was asked: «Do you know the term digital currency?». In comparison with local currency, potential users are more informed about the term of digital currency in each gender and 
experience categories. $65.1 \%$ of men and $67.3 \%$ of women, $73.4 \%$ less experienced and $63 \%$ of more experienced potential users know digital currency (the percentages for the term of local currency were as follows, respectively: $52.8 \%, 54.5 \%, 51.1 \%, 53.6 \%$ ).

Corresponding to differences between male and female respondents, $p$-values from the Chi-Square test and Z-score $(X 2=0,751, z=0,7489)$ are not significant at $5 \%$ level of significance. The $P$ values regarding experience are not significant $(X 2=0,664, z=0,6672)$ at the selected confidence level too. Those statistically insignificant results substantiate the fact that there are not any significant differences between awareness of female and male respondents and also less experienced and more experienced potential users regarding digital currencies.

Table 3. The knowledge of potential users regarding digital currency

\begin{tabular}{ccccc}
\hline \multirow{2}{*}{ Do you know the term digital currency? } & \multicolumn{2}{c}{ Gender } & \multicolumn{3}{c}{ Experience (years) } \\
\cline { 2 - 5 } Yes & Male & Female & \multicolumn{1}{c}{10 and less } & More than 10 \\
\hline \multirow{2}{*}{ No } & 233 & 37 & 69 & 201 \\
& $(65.1 \%)$ & $(67.3 \%)$ & $(73.4 \%)$ & $(63 \%)$ \\
\hline Total number of respondents & 125 & 18 & 25 & 118 \\
P-values from Chi-Square & $(34.9 \%)$ & $(32.7 \%)$ & $(26.6 \%)$ & $(37 \%)$ \\
P values from Z-score & 358 & 55 & 94 & 319 \\
\hline
\end{tabular}

Sources: developed by the authors.

Since this research does not find any significant differences between gender and experience of potential users regarding their knowledge about both terms, local and digital currencies, the research fails to support $\mathrm{H} 1$ and $\mathrm{H} 3$ hypotheses that are set up as the existence of significant differences between selected variables. In this regard, this research finds similar results with Shahzad et al. (2018). This is because Shahzad et al. (2018) do not find any significant relationship between gender and awareness of a digital currency's users. On the other hand, the results of this study contradict with the findings of Seyfang (2001), Williams et al. (2001), Gomez and Helmsing (2008), Carnero et al. (2015), Collom (2007) and Lasker et al. (2011) because these studies advocate the differences between male and female users of community currencies. Based on the results of experience and knowledge of the stated terms, this research also opposes to the findings of Carnero et al. (2015) and Bohr and Bashir (2014) to some extent. These researchers boost differences between the age of community currency users. Although it has a positive correlation with age, experience of potential users does not differ in this research regarding local and digital currency knowledge. This fact is the point that this research disproves the results of Carnero et al. (2015) and Bohr and Bashir (2014).

The similarities in the responses of men-women and less-more experienced potential users might stem from the publicity and prevalence of those currencies in the Czech Republic. As already illustrated in Table 2 and Table 3, more than half of the survey participants in all analyzed categories confirmed that they knew these terms. Since many community currency implementations have been taken part in the Czech Republic, the potential users might have been informed about them, and they might have been familiar with these terms. Another reason for similarities among potential users might stem from the effective interaction between the employees. People in working life are more likely to communicate and interact with their colleagues and share some information (Paloniemi, 2006). Having more informed people regarding CCs in a company also has impacts on influencing other workers' perception of CCs (Gregory and Gregory, 2009). For these reasons, the employees who know both terms might have informed their colleagues about these terms by communicating with them. This fact might present good evidence of why 
the respondents in all examined categories in this research have similar replies regarding their knowledge of these currencies.

Moreover, to indicate whether differences exist between gender and experience categories regarding trust of potential users for a paper-based local currency, Table 4 is presented below. According to these results, the percentages of respondents who trust a local paper currency differ from $13.5 \%$ to $17 \%$ in all gender and experience categories. Moreover, $20.1 \%$ of male $36.4 \%$ female, $31.9 \%$ of less experienced and $19.4 \%$ more experienced respondents would rather trust this currency.

On the other hand, more than one-third of male and more experienced respondents do not trust a paper currency, while one-fifth of female and less than one-fifth of less experienced potential users state that they do not trust this currency. Furthermore, the percentages of users who are not decided to trust a paper local currency vary from $27.9 \%$ to $36.2 \%$ in both gender and experience classifications. When running Chi-Square and Z-score tests, the answers of «Yes and Rather yes» and «No and I do not know» were combined. According to the results of these tests, $P$ values are significant regarding gender $(x 2=0,017, z=0,00001)$ and experience $(x 2=0,004, z=0,00466)$ at $5 \%$ confidence level. Therefore, it can be contended that there are differences between male and female and also less and more experienced respondents, and these differences are statistically significant. In comparison with men, women trust and would trust more to a paper currency. Moreover, more experienced users' trust to a local currency is lower than less experienced potential users.

Table 4. The trust of potential users regarding a local paper currency

\begin{tabular}{|c|c|c|c|c|}
\hline \multirow{2}{*}{$\begin{array}{l}\text { Would you trust a PAPER local currency that } \\
\text { is secured by a trusted entity (bank, state, } \\
\text { significant large private enterprise) and } \\
\text { whose exchange rate is firmly tied to the } \\
\text { Czech koruna? }\end{array}$} & \multicolumn{2}{|l|}{ Gender } & \multicolumn{2}{|c|}{ Experience (years) } \\
\hline & Male & Female & $\begin{array}{l}10 \text { and } \\
\text { less }\end{array}$ & More than 10 \\
\hline 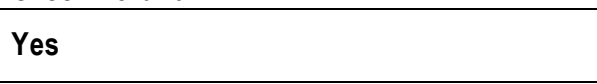 & $\begin{array}{c}51 \\
(14.2 \%)\end{array}$ & $\begin{array}{c}8 \\
(14.5 \%)\end{array}$ & $\begin{array}{c}16 \\
(17 \%)\end{array}$ & $\begin{array}{c}43 \\
(13.5 \%)\end{array}$ \\
\hline Rather yes & $\begin{array}{c}72 \\
(20.1 \%) \\
\end{array}$ & $\begin{array}{c}20 \\
(36.4 \%) \\
\end{array}$ & $\begin{array}{c}30 \\
(31.9 \%) \\
\end{array}$ & $\begin{array}{c}62 \\
(19.4 \%) \\
\end{array}$ \\
\hline No & $\begin{array}{c}128 \\
(35.8 \%)\end{array}$ & $\begin{array}{c}11 \\
(20 \%)\end{array}$ & $\begin{array}{c}14 \\
(14.9 \%)\end{array}$ & $\begin{array}{c}125 \\
(39.2 \%)\end{array}$ \\
\hline I do not know & $\begin{array}{c}107 \\
(29.9 \%)\end{array}$ & $\begin{array}{c}16 \\
(29.1 \%)\end{array}$ & $\begin{array}{c}34 \\
(36.2 \%)\end{array}$ & $\begin{array}{c}89 \\
(27.9 \%)\end{array}$ \\
\hline Total number of respondents & 358 & 55 & 94 & 319 \\
\hline $\begin{array}{l}\text { P-values from Chi-Square } \\
P \text { values from Z-score }\end{array}$ & \multicolumn{2}{|c|}{$\begin{array}{c}0,017 \\
0,00001\end{array}$} & \multicolumn{2}{|r|}{$\begin{array}{c}0,004 \\
0,00466\end{array}$} \\
\hline
\end{tabular}

Sources: developed by the authors.

Table 5 demonstrates the dissimilarities between gender and experience of potential users regarding their trust to a local digital currency. In line with the previously mentioned fact, the following responses "Yes and Rather yes» and «No and I do not know» were joined together. The p-values from the ChiSquare and Z-scores for gender $(x 2=0,0006, z=0,00068)$ and experience $(x 2=0,0001, z=0,00001)$ in Table 5 validate that statistically significant differences exist between men and women and also less experienced and more experienced potential users' trust to a local digital currency at $5 \%$ significant level. The percentage of male respondents who trust and would trust a local digital currency is $29.6 \%$, while this percentage for women potential users is $42.7 \%$. Concerning experience, more than half of less experienced respondents declare that they will trust or would trust a digital currency. In contrast, only $26.3 \%$ of more experienced users agree with their less experienced counterparts. However, $73.7 \%$ of 
more experienced respondents do not trust or do not know whether they will trust or not to this digital currency. The percentage of less experienced potential users for this fact is $45.7 \%$. The percentages of male and female respondents who answered «No and I do not know» options in the questionnaires are $70.4 \%$ and $47.3 \%$ respectively.

Table 5. The trust of potential users regarding a local digital currency

\begin{tabular}{lcccc}
\hline $\begin{array}{l}\text { Would you trust a DIGITAL local currency that } \\
\text { is secured by a trusted entity (bank, state, }\end{array}$ & \multicolumn{2}{c}{ Gender } & \multicolumn{2}{c}{ Experience (years) } \\
$\begin{array}{l}\text { significant large private enterprise) and whose } \\
\text { exchange rate is firmly tied to the Czech } \\
\text { koruna? }\end{array}$ & Male & Female & $\begin{array}{c}10 \text { and } \\
\text { less }\end{array}$ & More than 10 \\
\hline Yes & 39 & 7 & 14 & 32 \\
\hline Rather yes & $(10.9 \%)$ & $(12.7 \%)$ & $(14.9 \%)$ & $(10 \%)$ \\
\hline \multirow{2}{*}{ No } & 67 & 22 & 37 & 52 \\
& $(18.7 \%)$ & $(40 \%)$ & $(39.4 \%)$ & $(16.3 \%)$ \\
\hline I do not know & 134 & 11 & 19 & 126 \\
& $(37.4 \%)$ & $(20 \%)$ & $(20.2 \%)$ & $(39.5 \%)$ \\
\hline Total number of respondents & 118 & 15 & 24 & 109 \\
\hline P-values from Chi-Square & $(33 \%)$ & $(27.3 \%)$ & $(25.5 \%)$ & $(34.2 \%)$ \\
P values from Z-score & 358 & 55 & 94 & 319 \\
\hline
\end{tabular}

Sources: developed by the authors.

To sum up, the trust of potential users to local currencies (a paper and a digital) differ regarding their gender and work experience. Therefore, this research supports $\mathrm{H} 4$ hypothesis that supposes the existence of significant differences between gender and trust of potential users regarding local currencies. Moreover, it confirms that compared to male respondents, women potential users trust and would trust more to these currencies. In this line with this result, this research champions the studies that find differences between genders and better performance of women participants in comparison to men in the usage of community currencies (Seyfang, 2001; Gomez and Helmsing, 2008; Liebana-Cabanillas et al., 2018; Yeh et al., 2012; Carnero et al., 2015, Collom, 2007; Lasker et al., 2011). On the other hand, this result objects to the findings of Shazad et al. (2018) that find no differences between male or female users in their reliability of currencies. Similarly, this result of this study opposes to the finding of Jacob et al. (2003) and Wheatley et al. (2011) that contend men perform in this indicator than women.

Concerning experience and trust to local currencies, although a statistically significant difference exists between less and more experienced users, less experienced employees trust or would trust more than more experienced respondents. This fact makes this research to not to support $\mathrm{H} 2$ hypothesis that assumes the significant difference but supposes more experienced would trust more than less experienced employees. In line with this finding, this study disproves the result of Zeffane (2018) that enlightens positive impacts of work experience on tendency of trust. But Bohr and Bashir (2014) bear out that most of the digital currency users are young, and as mentioned previously in this research, less experience is positively correlated with younger ages. At this point, this research shows similarities with Bohr and Bashir (2014) since one of the results of this study reveals that less experienced employees trust or would trust more than more experienced potential users.

Concerning the reasons for the differences between gender and experience categories, the research provides some convincing pieces of evidence. The reason why female respondents trust or would trust to local currencies more than potential male users might be related with positive perception and higher 
adoption of women employees to these currencies. By having these attitudes, women respondents in this research might have had a more positive perspective about local currencies to trust them. Moreover, the education level of the female respondents might be another evidence why women trust more than men. That is because of the positive relationship between trust and education has been confirmed by some studies (Budak and Rajh, 2018; Charron and Rothstein, 2016). Moreover, some other researches also elucidate that more educated individuals are more prone to use community currencies (Carnero et al., 2015; Jacob et al., 2003).

In a similar vein, the existence of highly educated and less experienced potential users in this research might be the reason why they trust or would trust to local currencies more than more experienced respondents. Another reason why less experienced employees trust more to local currencies might be related to their interest to use new technologies and inventions. As less experienced individuals are usually young, their adaption to new currency systems creates fewer issues than older-more experienced people. That is because subjective norms influence less experienced users more and they trust more to new tools comparing to more experienced people (Liebana-Cabanillas et al., 2018). The investigated potential users in this current research might have highly impacted by their instincts. In this regard, this fact might explain why their propensity to trust these currencies is higher in comparison to more experienced employees.

Although awareness has been one of the major obstacles in usage and implementation of local currencies, majority of the potential users that are investigated for this research are informed about these currencies. On the other hand, the trust of the male and more experienced respondents in this research to local currencies is also prominent constraint to practice as this problem stated by other studies. For this reason, to increase trustfulness of local currencies and to decrease the concerns about their safety issues the practitioners might create a campaign or a promotion that aims to gain the trust of more experienced and male potential users. These campaigns and promotions might be put into practice by using media and advertising channels. Local events can be created to bring both potential users and practitioners together to make them interact with each other.

These practitioners that usually are non-governmental institutions or civil organizations should also behave as a guide to explain all details about the currencies to improve the trust of potential users. In this regard, some courses might be provided by the practitioners and the benefits in the usage of these currencies, the usage methods and exchange abilities of them with national currencies might be taught to potential users. Related to local digital currencies, applying blockchain technology can also generate advantages because this technology enables more visible and transparent transactions that can improve reliability. Moreover, getting supports from the governments to carry high importance because the government can secure the processes, can guarantee the exchange of these currencies with national currencies and can solve potential tax issues and these activities of the governments can increase the trustworthiness of these currencies. Those stated practices can not only improve the trustworthiness of local currencies but also increase awareness of them among potential users and make potential users participate in these actions.

Conclusions. Local currencies play crucial roles in the development of local economies, social relations of local people and finding effective solutions for local environmental issues. Although local currencies have positive influences on economic, social and environmental factors, implementing these currencies to a restricted geographical region is a challenging activity for its practitioners especially, to gain the trust of potential users and create awareness among them. By focusing on these obstacles, this research aims to discover differences between gender and work experience of potential users. To the best of the authors' knowledge, there are no studies in the literature investigating these characteristics of potential local currency users and determining differences in their trust and knowledge about these currencies. For these reasons, practitioners, governments, non-governmental organizations and financial institutions can gain benefits from the results of this sole research. 
In parallel with the specified purpose, the researchers use data from 413 employees that have been working in Cieszyn Silesia region. To collect the data, the authors applied a questionnaire survey that consisted of questions regarding the characteristics and the perceptions of potential users about local currencies. To find statistically significant differences between selected variables, Chi-Square, Pearson statistics and Z-score tests performed in SPSS Statistical Software. The results from the analyzes substantiate that there are no statistically significant differences between local currency awareness of potential users regarding their gender and work experience. The reasons why this research confirms nonexistence of statistically significant differences in the local currency knowledge of the respondents might be related with promotion and common examples of these currencies in the market and mutual communications between the potential users.

Concerning differences between trust of the respondents, statistically significant differences exist in both gender and experience categories. In comparison with female respondents, male employees are less prone to trust local currencies. The reason for the difference between genders might be due to education, perception and adoption of women potential users to local currencies. Moreover, less experienced potential users are more likely to trust local currencies than their more experienced counterparts. Education, instincts and being interested in novel technologies might be the potential pieces of evidence for the differences between work experiences of the respondents.

For minimizing the concerns of more experienced and male potential users about the security of local currencies, advertisements and events can be created, and media tools might be applied to show how the processes and usage of local currencies are secured. A guidance role should be played by practitioners in these activities and in some courses to tell every detail about the usage and benefits of the currencies. These activities also enable potential users to be more informed about local currencies and improve their awareness. Using a safer technology such as blockchain especially in digital currencies and gaining the governments' supports and encouragements might also be substantial actions to take for practitioners to increase the reliability of these currencies. Applying these solutions can ease the usage of these currencies and increase the number of participants.

Except for its' created values for the academic literature, this research has some limitations. This study is only limited to a region, and the respondents are only employees. Other limitations are that this research examines two obstacles of the implementations of local currencies and two characteristics of respondents, namely, age and work experience. Moreover, the perceptions of potential users only gained for local (paper based-digital) currencies. For these reasons, further studies might consider more regions from various countries and their local currencies to compare and find national and international differences between them. The data of further researches can include unemployed people, and these studies can investigate other characteristics of respondents such as their age, marital status and education levels. Other types of community currencies should be taken into consideration to discover potential dissimilarities among users of various currency types. By considering these facts, the researchers can do more comprehensive researches with wider perspectives.

Author Contributions: conceptualization, A. K., M. C.; methodology, A. K., M. C.; validation, M. C., A. K.; resources, A. K., V. K.; data curation, A. K., V. K.; writing-original draft preparation M. C.; writing review and editing A. K., J. P.; visualization M. C.; supervision, V. K., J. P.; project administration, A. K., V. K.

Funding: This research was funded by the Technology Agency of the Czech Republic TACR, grant number (TL02000562).

\section{References}

Ali, R., Barrdear, J., Clews, R., \& Southgate, J. (2014). Innovations in payment technologies and the emergence of digital 
currencies. Bank of England Quarterly Bulletin, Q3. [Google Scholar]

Baranovskyi, O. I. (2020). Regulation of functional and structural transformational processes in the financial sector. Financial and credit activity: problems of theory and practice, 1(32), 292-306. [Google Scholar] [CrossRef]

Baranovskyi, O. I. (2018). Quality of the transformational processes in the financial sector of the national economy: vectors of the measurement. Financial and credit activity: problems of theory and practice, 3(26), 350-367. [Google Scholar] [CrossRef]

Bilan, Y., Mishchuk, H., Roshchyk, I., \& Kmecova, I. (2020). An Analysis of Intellecutal Potential and its Impact on the Social and Economic Development of European Countries. Journal of Competitiveness, 12(1), 22. [Google Scholar] [CrossRef]

Blanc, J. (2011). Classifying "CCs": Community, complementary and local currencies'types and generations. International Journal of Community Currency Research, 15(D), 4-10. [Google Scholar] [CrossRef]

Bohr, J., \& Bashir, M. (2014, July). Who uses bitcoin? an exploration of the bitcoin community. In 2014 Twelfth Annual International Conference on Privacy, Security and Trust (pp. 94-101). IEEE. [Google Scholar] [CrossRef]

Bonanno, A. (2018). Assessing local mutual credit as a socio-economic tool for farmers in New York states Hudson Valley. International Journal of Community currency Research, 22, 89-102. [CrossRef]

Brenes, E. (2011). Complementary currencies for sustainable local economies in Central America. International Journal of Community Currencies Research, 15, 32-38. [Google Scholar] [CrossRef]

Budak, J., \& Rajh, E. (2018). Citizens' Online Surveillance Concerns in Croatia. Surveillance \& Society, 16(3), 347-361. [Google Scholar] [CrossRef]

Buriak, A., Voznakova, I., Sułkowska, J., \& Kryvych, Y. (2019). Social trust and institutional (Bank) trust: Empirical evidence of interaction. Economics \& Sociology, 12(4), 116-332. [Google Scholar] [CrossRef]

Carnero, M. A., Martinez, B., \& Sanchez-Mangas, R. (2015). Explaining transactions in time banks in economic crisis. Applied Economics Letters, 22(9), 739-744. [Google Scholar] [CrossRef]

Carter, L., Weerakkody, V., Phillips, B., \& Dwivedi, Y. K. (2016). Citizen adoption of e-government services: Exploring citizen perceptions of online services in the United States and United Kingdom. Information Systems Management, 33(2), 124-140. [Google Scholar] [CrossRef]

Charron, N., \& Rothstein, B. (2016). Does education lead to higher generalized trust? The importance of quality of government. International journal of educational development, 50, 59-73. [Google Scholar] [CrossRef]

Civelek, M., Kljucnikov, A., Krajcík, V., \& Žufan, J. (2019). The Importance of Discount Rate and Trustfulness of A Local Currency for the Development of Local Tourism. Journal of Tourism and Services, 10(19), 77-92. [Google Scholar] [CrossRef] Colacelli, M., \& Blackburn, D. J. (2009). Secondary currency: An empirical analysis. Journal of Monetary Economics, 56(3),

295-308. [Google Scholar] [CrossRef]

Collom, E. (2007). The motivations, engagement, satisfaction, outcomes, and demographics of time bank participants: survey findings from a US system. international Journal of Community Currency research, 11(1), 36-83. [Google Scholar] [CrossRef]

Della Peruta, M., \& Torre, D. (2014). Virtual Social Currencies for Unemployed People: Social Networks and Job Market Access (No. 2014-16). Groupe de REcherche en Droit, Economie, Gestion (GREDEG CNRS), Universite Côte d'Azur, France. [Google Scholar]

Frankova, E., Fousek, J., Kala, L., \& Labohý, J. (2014). Transaction network analysis for studying Local Exchange Trading

Systems (LETS): Research potentials and limitations. Ecological Economics, 107, 266-275. [Google Scholar] [CrossRef]

Gimenez, A. F. C., \& Tamajón, L. G. (2019). An analysis of the process of adopting local digital currencies in support of sustainable development. Sustainability, 11(3), 1-19. [Google Scholar] [CrossRef]

Ginevicius, R. (2019). Quantitative assessment of the compatibility of the development of socioeconomic systems. Journal of Competitiveness, 11(2), 36. [Google Scholar] [CrossRef]

Gomez, G. M., \& Helmsing, A. H. J. (2008). Selective spatial closure and local economic development: What do we learn from the Argentine local currency systems?. World Development, 36(11), 2489-2511. [Google Scholar] [CrossRef]

Gregory, L., \& Gregory, L. (2009). Change takes time: Exploring structural and development issues of time banking. International Journal of Community Currency Research, 13, 19-32. [CrossRef]

Jacob, J., Brinkerhoff, M., Jovic, E., \& Wheatley, G. (2004). The social and cultural capital of community currency: an Ithaca

HOURS case study survey. International Journal of Community Currency Research, 8(4), 42-56. [Google Scholar] [CrossRef]

Jelínek, P., Szalay, Z. E., \& Konecný, A. (2012). Local exchange trade systems in central European post communist countries. International journal of community currency research, 16(D), 116-123. [Google Scholar] [CrossRef]

Josavac, M. (2017). The bright and the dark side of virtual currencies recent development in regulatory framework. Journal of Community Currency Research, 21(2), 1-18.

Khan, K. A., Cera, G., \& Netek, V. (2019). Perception of the selected business environment aspects by service firms. Journal of Tourism and Services, 10(19), 111-127. [Google Scholar] [CrossRef]

Kichiji, N., \& Nishibe, M. (2008). Network analyses of the circulation flow of community currency. Evolutionary and Institutional Economics Review, 4(2), 267-300. [Google Scholar] [CrossRef]

Kim, S. M., Lough, B., \& Wu, C. F. (2016). The conditions and strategies for success of local currency movements. Local Economy, 31(3), 344-358. [Google Scholar] [CrossRef]

Kljucnikov, A., Civelek, M., Cech, P., \& Kloudova, J. (2019). Entrepreneurial orientation of SMEs' executives in the comparative perspective for Czechia and Turkey. Oeconomia Copernicana, 10(4), 773-795. [Google Scholar] [CrossRef] 
Koisova, E., Masarova, J., \& Habanik, J. (2018). Regional differences in the labour market in Slovakia and the Czech Republic. Journal of Competitiveness, 10(2), 104. [Google Scholar] [CrossRef]

Lasker, J., Collom, E., Bealer, T., Niclaus, E., Young Keefe, J., Kratzer, Z., ... \& Suchow, D. (2011). Time banking and health: the role of a community currency organization in enhancing well-being. Health promotion practice, 12(1), 102-115. [Google Scholar] [CrossRef]

Liebana-Cabanillas, F., Munoz-Leiva, F., \& Sanchez-Fernandez, J. (2018). A global approach to the analysis of user behavior in mobile payment systems in the new electronic environment. Service Business, 12(1), 25-64. [Google Scholar] [CrossRef]

Marshall, A. P., \& O'Neill, D. W. (2018). The Bristol Pound: A tool for localisation?. Ecological Economics, 146, 273-281. [Google Scholarl [CrossRef]

Michel, A., \& Hudon, M. (2015). Community currencies and sustainable development: A systematic review. Ecological economics, 116, 160-171. [Google Scholar] [CrossRef]

$\mathrm{Ng}, \mathrm{T}$. W., \& Feldman, D. C. (2009). Age, work experience, and the psychological contract. Journal of organizational behavior, 30(8), 1053-1075. [Google Scholar] [CrossRef]

Nwaiwu, F. (2018). Review and comparison of conceptual frameworks on digital business transformation. Journal of Competitiveness. [Google Scholar] [CrossRef]

Onuferova, E., \& Cabinova, V. (2018). Enterprise performance analysis of the selected service sector by applying modern methods with an emphasis on the creation and application of the modified creditworthy model (MCWM). Journal of tourism and services, 9(17). [Google Scholar] [CrossRef]

Paloniemi, S. (2006). Experience, Competence and Workplace Learning. Journal of Workplace Learning, 18, 439-450. [Google Scholar] [CrossRef]

Pena de Carrillo, C. I., Rosa, J. L. D. L., Carrillo Pena, P. N., \& Pharow, P. (2018). Identification of barriers and solutions for adoption of social, complementary and/or virtual currencies. @ International Journal of Community Currency Research, 2018 (Summer), vol. 22, p. 125-140. [Google Scholar] [CrossRef]

Sanz, E. O. (2016). Community currency (CCs) in Spain: An empirical study of their social effects. Ecological Economics, 121, 20-27. [Google Scholar] [CrossRef]

Seyfang, G. (2001). Money that makes a change: Community currencies, North and South. Gender \& Development, 9(1), 6069. [Google Scholarl [CrossRef]

Seyfang, G. (2005). Community currencies and social inclusion: A critical evaluation (No. 05-09). CSERGE Working Paper EDM. [Google Scholar]

Seyfang, G., \& Longhurst, N. (2013). Growing green money? Mapping community currencies for sustainable development. Ecological Economics, 86, 65-77. [Google Scholar] [CrossRef]

Shahzad, F., Xiu, G., Wang, J., \& Shahbaz, M. (2018). An empirical investigation on the adoption of cryptocurrencies among the people of mainland China. Technology in Society, 55, 33-40. [Google Scholar] [CrossRef]

Sobiecki, G. (2018). Sustainability of local complementary currencies: conclusions from an empirical study in Poland. International Journal of Community Currency Research, 22. [CrossRef]

Stacho, Z., Stachova, K., \& Raišienè, A. G. (2019). Changes in approach to employee development in organizations on a regional scale. Journal of International Studies, 12(2). [Google Scholarl [CrossRef]

Valek, L. (2012). Development of a complementary currency system: the Czech position in the international context. Journal of Innovation Management in Small \& Medium Enterprises, 2012, 1. [Google Scholar] [CrossRef]

Vovchak, O. D., Senyshch, P. M., \& Melnyk, T. V. (2019). «Purging» of the banking system: impacton the key performance indicators of banks. Financial and credit activity: problems of theory and practice, 1(28), 16-25. [Google Scholar] [CrossRef]

Walker, D. (2009). The impact of community currency systems on gender relations in rural northeast Thailand: a hybrid social audit-gender analysis approach. International Journal of Community Currency Research, 13, 36-60. [CrossRef]

Wheatley, G., Younie, C., Alajlan, H., \& McFarlane, E. (2011). Calgary dollars: economic and social capital benefits. International Journal of Community Currency Research, 15(1), 84-89. [CrossRef]

Williams, C. C., Aldridge, T., Lee, R., Leyshon, A., Thrift, N., \& Tooke, J. (2001). Bridges into work? An evaluation of local exchange and trading schemes (LETS). Policy studies, 22(2), 119-132. [Google Scholar] [CrossRef]

Yeh, J. C., Hsiao, K. L., \& Yang, W. N. (2012). A study of purchasing behavior in Taiwan's online auction websites. Internet Research. [Google Scholar] [CrossRef]

Ying, S. H. (2004, March). When poverty comes with globalization: How does community currency empower individuals?". In ISA Symposium on (Vol. 16). [Google Scholar]

Zeffane, R. (2018). Do age, work experience and gender affect individuals' propensity to trust others? An exploratory study in the United Arab Emirates. International Journal of Sociology and Social Policy. [Google Scholar] [CrossRef] 
Олександр Ключніков, Ph.D., Вища школа підприємництва та права, Чехія

Мехмет Сівелек, Ph.D., Вища школа підприємництва та права, Чехія

Володимир Крайчик, Ph.D., Вища школа бізнесу в Празі, Чехія

Іржі Полач, профресор, Вища школа бізнесу в Празі, Чехія

Ставлення споживачів до впровадження місцевої валюти

У статті висвітлено особливості та проблеми впровадження місцевих валют у обраних географрічних регіонах. Авторами зазначено, що підвищення рівня обізнаності та довіри серед потенційних користувачів сприяє популяризації місцевих валют. Головною метою дослідження $є$ визначення відмінностей між довірою та знаннями потенційних користувачів про місцеві валюти в залежності від гендерного фрактору та досвіду роботи. Детерміновану вибірку даних сформовано на основі результатів опитування 413 респондентів, які працюють в Чешині Сілезького регіону. Методологію дослідження засновано на статистичному тесті Xi-квадрат та стандартизованій Z-оцінці. У ході практичної реалізації дослідження застосовано програмне забезпечення SPSS для визначення статистично значущої різниці між визначальними змінними. За результатами встановлено відсутність статистично значущого впливу гендерного фактору та досвіду роботи на рівень знань потенційних користувачів про місцеві валюти. До того, більшість респондентів продемонстрували високий рівень освіченості в досліджуваному питанні. Авторами припущено, що реклама та поширеність місцевих валют, а також тісна взаємодія між співробітниками обумовлюють високий рівень обізнаності потенційних користувачів про місцеві валюти. Окрім цього, отримані результати дослідження засвідчили, що гендерний фактор та досвід роботи мають вплив на рівень довіри до місцевих валют. Таким чином, респоденти чоловічої статі та працівники з більшим досвідом роботи мають нижчий рівень довіри до місцевих валют. У статті авторами доведено, що причинами таких відмінностей можуть бути різний рівень освіти, рівні сприйняття та прийняття, інстинкти та особисті інтереси потенційних користувачів у місцевих валютах. Результати дослідження мають практичне значення для установ, організацій, уряду та спеціалістів та можуть бути розглянуті при поширенні місцевих валют в цілях підвищення рівня конкурентоспроможності менш розвинених регіонів. роботи.

Ключові слова: свідомість, Чешин Сілезького регіону, валюта, цифрова валюта, стать, місцева валюта, довіра, досвід

Manuscript received: 11.03.2020

(C) The author(s) 2020. This article is published with open access at Sumy State University 